\title{
The Extent of Rent Sharing along the Wage Distribution
}

\author{
Alessia Matano ${ }^{1}$ and Paolo Naticchioni ${ }^{2}$ \\ word count [9920]
}

February 2017

\begin{abstract}
The relation between rent sharing and wages has generally been evaluated on average wages. This paper uses a unique employer-employee panel database to investigate the extent of rent sharing along the wage distribution in Italy. We apply quantile regression techniques and control for national level bargaining, unobserved worker and firm heterogeneity and endogeneity. Our findings show that the extent of rentsharing decreases along the wage distribution, suggesting that unskilled workers benefit most from firms' rents. By applying quantile regressions by occupational categories, we show that the decreasing pattern is mainly driven by blue collar workers, while estimates for white collars are higher and basically constant along the wage distribution. We also provide evidence that unions might represent one of the driver of our findings.
\end{abstract}

JEL Classification: C33, J31, J41, L25.

Keywords: Rent Sharing, Wage Distribution, Quantile Regressions, IV Quantile regressions, Quantile fixed effects regressions.

\section{Introduction}

European countries are usually taken as examples for non-competitive labor markets because of the important role played by labor market institutions. The economic literature has largely investigated how wage setting works in non-competitive labor markets, and how rent sharing can emerge in such markets. Non-competitive theories, such as efficiency wage and bargaining models, can predict a positive relationship between wages and profits. In particular, bargaining models underline that wages result from a bargain between employer and employees which generates a long-run 
positive relation between wages and profits. In this setting, wages are determined by workers' outside options, by quasi-rent (firm profits evaluated at the opportunity cost of labor) and by the relative bargaining power of the parties involved (Hildreth and Oswald, 1997).

At the empirical level many papers have tested the existence and extent of rent sharing (Abowd and Lemieux, 1993, Van Reenen, 1996, Margolis and Salvanes, 2001, Martins, 2009, Card et al., 2014, etc.). However, these analyses have generally been carried out taking into account average wages. In this way there can be no insight into the distributional consequences of rent sharing, i.e. it is not possible to take into account the difference in the degree of rent sharing for workers located at different points of the distribution.

The aim of this paper is to evaluate the degree of rent sharing along the whole wage distribution in order to achieve a better understanding of the mechanisms behind the relation between profits and wages. Previous empirical investigations have analyzed rent sharing across categories of workers, defined by education and by occupation. The main drawback using this approach is that workers belonging to the same education/occupation level are usually associated to very high within group wage heterogeneity. For instance, according to the 1996 data of the European Community Household Panel, almost 50\% of Italian graduates were not employed in the top quartile of the wage distribution, and around $20 \%$ had a wage lower than the median, suggesting a substantial heterogeneity within educational levels. A similar argument can be applied when considering blue collar and white collar workers, where especially in the white collar category secretaries coexist with managers, with huge differences in terms of productivities and wages. We make use of quantile regressions methodologies to deal with this heterogeneity, since percentiles of the wage distribution can be more closely associated to the productivity of workers in the labor market.

Furthermore, there could be various different reasons why rent sharing is not uniform along the workers' wage distribution. On the one hand, it might be argued that if bargaining at the firm level was mainly organized by unions, low and median skilled workers might enjoy a higher degree of rent sharing than high skilled workers. This channel refers to the robust evidence concerning the distributional goals of unions that mainly represent the interest of low skilled workers (Di Nardo et al., 1996; Card, 1996; Frandsen, 2012). On the other hand, if bargaining occurred mainly at the 
individual level, rent sharing might favor high skilled workers, who can benefit from higher individual bargaining power and performance pay schemes (Lemieux et al., 2009). Hence, given the ambiguous theoretical predictions, the analysis of rent sharing along the wage distribution is mostly an empirical issue, and to the best of our knowledge this is the first paper that addresses this issue along the whole wage distribution.

In our analysis we make use of a unique employer-employee panel database from 1996 to 2003 for Italy, constructed by merging the INPS (the Italian Social Security Institute) employer-employee panel database with the AIDA database (provided by Bureau Van Dick) which contains detailed information on the balance sheets of the Italian capital-owned firms.

On the econometric side, our empirical analysis takes into account all the issues which have been proved to be relevant when addressing the relationship between rents and wages.

We begin by estimating the impact of quasi-rents on wages using cross-sectional quantile regressions (Koenker and Basset, 1978), controlling for observed worker and firm heterogeneity. In the estimation we use as proxy for the opportunity cost of labor the minimum wage corresponding to the national contract applied to each worker and, within the national contract, to the exact occupation level ('livello di inquadramento') the worker belongs to. We argue that this is an accurate measure to control for the opportunity cost of labor mainly because in such a way it is possible to control in the estimates for the first national collective bargaining level, since minimum wages in Italy are formally bargained at the national level between unions and employer associations. The cross-section estimates show that the impact of rent sharing is positive for all percentiles analyzed and decreases along the wage distribution: rent sharing elasticities range from $5.4 \%$ at the $10^{\text {th }}$ wage percentile to $4.3 \%$ at the $90^{\text {th }}$ wage percentile.

A second step in the analysis is to control for the unobserved worker and firm heterogeneity, which can affect the relationship between profits and wages (Card et al., 2014, Arai and Heyman, 2001, Margolis and Salvanes, 2001, Martins, 2009). By applying quantile job-match fixed effects estimates (Canay, 2011), that explicitly take into account the individual and firm unobserved heterogeneity, the impact of rent 
sharing is significantly reduced along the whole wage distribution and rent sharing elasticities are still slightly decreasing along the wage distribution.

The last step of the empirical analysis investigates the endogeneity issue, which has been proved to be a serious concern in the analysis of rent sharing since endogeneity could cause serious coefficients underestimation (Card et al., 2014, van Reenen, 1996), an underestimation which could even be exacerbated by the introduction of fixed effects in the specification (Nickell, 1981). Therefore, we apply IV quantile fixed effect estimation techniques (Galvao, 2011, Galvao and Montes-Rojas, 2010). For the instrument, we exploit the intuition developed in Card et al. (2014) by using a weighted average of the real sales per employee in other provinces of Italy in the same 3-digit industry. The idea is that real sales per employee in the same industry - which represents national industry demand shocks - affect the profitability of the firms. Further, these sales relate to firms in other provinces of Italy and are therefore assumed to be uncorrelated with local labor market conditions. Consistently with the related literature, by applying an IV methodology estimates increase along the whole wage distribution and by a large extent, thus pointing out that previous fixed effects estimates suffered by a serious degree of underestimation. In particular, the elasticity of wages with respect to rents stands at $7.3 \%$ at the $10^{\text {th }}$ percentile, $6.1 \%$ at the median and $5.0 \%$ at the $90^{\text {th }}$ percentile, confirming that the degree of rent sharing is decreasing along the wage distribution.

We also explore the heterogeneity of rent sharing within occupational categories by applying our preferred specification separately for blue collars and white collars. In such a way we integrate our approach based on quantile regressions with the standard sample split approach by occupational categories. To the best of our knowledge, this represents an original contribution of the paper, aimed at capturing the large heterogeneity within occupational categories. Interestingly, results show that, on average, the decreasing pattern uncovered in the main estimates is mainly driven by the results for blue collar workers. Estimates for white collars are higher and basically constant along the wage distribution, consistently with the intuition that high skilled workers might have higher individual bargaining power (Arai and Heyman 2001; Martins, 2009; Guertzen, 2009).

As a possible explanation for our findings, we investigate the role of union, which in Italy represents an important actor in the bargaining process between workers and employers. Indirectly, this also allows us to address the role of individual bargaining, 
defined as the rent sharing left once having controlled for the role of unions, observed and unobserved individual and firm heterogeneity, national bargaining and endogeneity issues. We test this possible explanation exploiting the regional/sectoral variability in the percentage of unionized firms, considered as a proxy for union power in the bargaining process at the local/firm level. Focusing on the manufacturing sector, we introduce in our preferred specification an interaction term between the quasi-rent variable and a dummy indicating high union presence. Also in this case we analyze the results separately for blue collars and white collars, and interesting differences emerge. As for blue collar workers, unions seem to represent a driving force at all percentiles of the distribution, but the union effect is stronger for the unskilled blue collars, suggesting that unions mainly care about unskilled welfare (Di Nardo et al., 1996; Card, 1996). For white collars, still the interaction with unions seems to be a crucial driver for workers at the $10^{\text {th }}$ and $50^{\text {th }}$ percentiles, while individual bargaining emerges to be a not negligible driver for the rent sharing accruing to the high skilled workers. Nonetheless, we want to stress that the latter findings have to be taken with some cautious, because of the imperfect proxy of union power we use and of the assumption of union exogeneity.

The structure of the paper is as follows. In Section 2 we review the theoretical and empirical literature on the relationship between profits and wages. In Section 3 we describe the data we use throughout the empirical analyses. Section 4 discusses the empirical specification and presents the main results. Section 5 concludes.

\section{Related Literature}

Non-competitive theories underline that firms may pay a wage over the level set in the competitive labor market for various different reasons. First, it is possible that firms pay higher wages on the basis of efficiency wage arguments (see Shapiro and Stiglitz, 1984, Krueger and Summers, 1988). Second, according to bargaining theories, profits and wages can move together due to the bargaining over wages between employers and employees. More specifically, in a bargaining framework, wages at the firm level are determined by workers' outside options, by the quasi-rent (firm profits evaluated at the opportunity cost of labor) and by the relative bargaining power of the parties involved (Hildreth and Oswald, 1997). ${ }^{3}$ 
As for the empirical evidence, many studies explore the existence and the extent of rent sharing in different countries, using various methodologies and various kinds of data. Hildreth and Oswald (1997) make use of firm level data for the UK providing evidence in favor of a significant positive relationship between profits and wages, controlling for observed work heterogeneity and firm characteristics and applying GMM techniques (or using lagged values of profits) to control for the endogeneity of profits. Similar findings are derived by Blanchflower, Oswald and Sanfey (1996) for the US, using industry level data matched with individual data.

Other papers use instrumental variables techniques to control for the endogeneity of profits. Abowd and Lemieux (1993), in the case of Canada, use instruments related to international performance, namely the industry import and export prices, finding a very large degree of underestimation in the extent of rent sharing when not controlling for the endogeneity between profits and wages. Van Reenen (1996) analyzes the case of the UK using different measures for profits and past innovations as instruments. His findings suggest a substantial amount of rent sharing in the UK, and serious underestimation when not controlling for endogeneity.

More recently, various papers have made use of matched employer-employee panel data in order to control for unobserved worker and firm heterogeneity. Margolis and Salvanes (2001) investigate the case of France and Norway. They apply IV techniques using as instruments sales and operating subsidies, finding relevant rent sharing only in the case of Norway. For France, when taking into account the unobserved individual heterogeneity in the IV estimation, rent sharing estimates are not significant. Similarly, using employer-employee data Arai (2003) analyzes the case of Sweden. He uses timeaverage of lagged values of profits as instruments and controls for observable firm characteristics. He finds robust evidence of rent sharing, in line with bargaining theories, and this effect does not differ across the different worker categories. In another related paper, Arai and Heyman (2001) make use of a larger employeremployee matched, providing evidence of higher rent sharing for white collar workers with respect to blue collars, and for the service sector with respect to manufacturing. They also apply instrumental variable techniques, using different instruments such as lagged values of profits, demand elasticity and measures indicating the degree of competition in the product market.

Also Martins (2009) makes use of matched employer-employee panel data to derive evidence of rent sharing for Portugal in the period 1993-1995. His findings strongly 
support the need to take into account the role of both the unobserved individual and firm heterogeneity, as well as endogeneity (the interaction between the exchange rate and the share of total exports in sales is used as instrument). Further, he shows that rent-sharing is substantially higher for better educated workers.

Another interesting paper is Guertzgen (2009), which focuses on how rent sharing is affected by the different levels of bargaining in Germany, using firm-worker level data and GMM techniques. She shows that rent sharing is higher where there is no collective agreement coverage and in the presence of firm-specific contracts. Moreover, she also shows that blue collar workers in uncovered establishments seem to benefit more from the local bargaining power of works councils, i.e. local unions, and that high educated workers display higher rents.

Rusinek and Rycx (2013) also analyze the impact of different levels of bargaining (industry and firm level) on the extent of rent sharing, using an employer-employee database for Belgium. Their results show that, after controlling for the endogeneity of profits and heterogeneity among workers and firms, in industries where agreements are more likely to be renegotiated at firm-level ('decentralized industries'), wages and profits are positively correlated regardless of the type of collective wage agreement. On the contrary, where firm-level wage renegotiation is less likely ('centralized industries'), wages are only significantly related to profits for workers covered by a firm-level collective agreement. ${ }^{4}$

As for Italy, empirical evidence on rent sharing is somewhat wanting. One of the few exceptions is the paper by Card et al. (2014), which analyzes the degree of rent sharing and tests the hold-up hypothesis in the Italian region of Veneto in 1995-2001. By using INPS-AIDA matched employer-employee data, they perform an accurate analysis taking into account all the relevant issues needed to identify the extent of rent sharing (the workers' and firms unobserved heterogeneity and the endogeneity of profits). Their findings show that there is evidence of a substantial degree of rent sharing in Veneto, and that profits are shared with workers after capital costs are fully deducted from profits. ${ }^{5}$

\section{The Italian Institutional Setting and Data Description}

The institutional issues related to this paper concern the Italian wage setting. Since the beginning of the nineties there has been a two-level wage bargaining system, which is 
similar to schemes used in other European countries such as Germany. The first level concerns national collective bargaining, which has to preserve the purchasing power of wages at the sector level by incorporating the expected inflation rate in wage increases. This is done by setting minimum wages for all workers covered by the related National collective agreements, which are renewed every 2-4 years. Minimum wages are different in each industry, and within industries different minimum wages are assigned to different workers in different occupation levels ('livelli di inquadramento'): this means that minimum wages are settled, at different levels, for blue collar workers, white collar workers and managers.

The second level of bargaining is decentralized, and encourages rent sharing through performance-related pay schemes at the region/firm level. 6 This second level is not compulsory for firms and unions, while it is compulsory respecting the lower bound set by the minimum wage of the first national bargaining level.

As for the data, we use a panel version of the administrative database provided by INPS (Italian Social Security Institute) and elaborated by ISFOL. ${ }^{7}$ It is a matched employee-employer dataset, constructed by merging the INPS employee information database for the period 1985-2003 with the INPS employer information database. ${ }^{8}$ The database contains individual information such as age, gender, occupation, workplace, date of beginning and end (if any) of the current contract, the kind of national contract and the related minimum wage, the social security contributions, the worker status (part-time or full-time), the real gross yearly wage and the number of weeks worked. We then have some information concerning the firm such as the plant location (province), the number of employees and the sector (NACE Rev.1.1). We focus on male and female workers, aged between 15 and 64 (when they first enter the database), working in the industrial and service sectors, both part-time (converted into full-time equivalent) and full-time, employed in standard labor market contracts: blue collar and white collar workers (excluding managers and apprenticeship workers). We derive the panel version considering only one observation per year for each worker. For workers who display more than one observation per year we selected the longest available contract in terms of weeks worked. ${ }^{9}$

We merge the INPS panel dataset with the AIDA database, from 1996 to 2003. AIDA is a database on Italian (capital-owned) firms provided by Bureau Van Dijk that contains information on the balance sheet such as value added, profits, sales, production and costs of production. ${ }^{10}$ 
The two databases are merged by using as key variable the tax code or the VAT number (codice fiscale or partita IVA) of the company, in such a way restricting the analysis to the capital-owned firms. ${ }^{11}$ After the merge, we recover our final estimation sample largely following the approach outlined in Card et al. (2014), a reference paper in the field, which uses the same INPS-AIDA data, although restricted to the Veneto region. In particular, we eliminate those observations where the difference in the firm size reported in AIDA and the one reported in INPS exceeds 100 (in this way the correlation between the firm size reported in AIDA and the firm size reported in INPS is 0.99). We also drop firms with less than 15 employees, since these firms are exempted from many labour regulations and we exclude the "construction" and "mining" sectors. Further, we eliminate extreme observations below (above) the $1^{\text {st }}$ (99th) percentile of the wage, profits per employee and total personnel costs variables, used to build the quasi-rent variable. Finally, we drop workers for whom data on the minimum wage are not available. In fact, our database does not include minimum wages for the - nearly - 300 national contracts. We have this information for the 39 major contracts, which nonetheless cover more than $75 \%$ of the whole sample. Table A1 in the Appendix shows the details of the steps implemented from the original INPS data to the final sample estimation. The table shows that after the merge with AIDA (comparison between columns (1) and (2)), the firm size increases as well as both the average and minimum wage. This is due, as already stressed, to the fact that in AIDA only capital-owned firms with turnover higher than 500,000 euro are included. These firms are in general larger, and due to the positive empirical relation between firm size and wages, also the average wages turn out to be larger. Therefore, we stress that this analysis is representative for the capital-owned firms with a turnover higher than 500,000 euro and not of the universe of Italian firms. This is not unusual for empirical analyses that make use of balance sheet data that are available in most of the countries only for capital-owned firms. As for the following steps of the sample selection, table A1 shows that when passing from the matched INPS-AIDA sample (column (2)) to the panel estimation sample (column (3)), i.e., by eliminating the outliers data, there is a slight reduction in the average firm size, average quasi-rents and average wage variables. The next steps (columns (4) and (5)) do not entail significant changes in the characteristics of the sample (all details are included in the legend of Table A1).

In this way, we end up with an employer-employee panel database constituted by 38,810 workers for 157,600 observations for the period 1996-2003. 


\section{Econometric Analysis}

\subsection{Econometric Strategy}

In this section we present our empirical strategy for investigating the impact of rents on wages. Since our focus is on the relationship between rents and wages along the wage distribution, we start by performing standard quantile regressions (Koenker and Bassett, 1978). We use the INPS-AIDA employer-employee database from 1996-2003. The baseline specification is quite standard in the rent sharing literature (see for instance Van Reenen, 1996), and it is as follows:

$$
\begin{aligned}
& \ln \left(w_{\theta(i, t)}\right)=\alpha_{\theta}+\chi_{\theta} * \ln M W_{c(i, t)}+B_{\theta}^{\prime} * I_{-} \text {Char }_{i, t}+\beta_{\theta} * \ln \text { Firmsize }_{j(i, t)}+ \\
& +\gamma_{1, \theta} * \ln \text { Quasi } \operatorname{Re} n t s_{j(i, t)}+\phi_{s, \theta}+\lambda_{a, \theta}+\delta_{t, \theta}+\varepsilon_{i, t, \theta}
\end{aligned}
$$

where $\theta$ refers to the percentile, $i$ to individuals, $j(i, t)$ to the firm where the worker $i$ is employed at time $t, c(i, t)$ to the national contract (along with its level) the worker is subject to, $s$ to industry. The dependent variable, the (log) real gross weekly wage in euro, ${ }^{12}$ includes all components of gross wages (base wage, overtime payments and bonuses). As main independent variable we use the quasi-rent per worker defined as rents per worker evaluated at the opportunity cost of labor, QuasiRents $s_{j(i, t)}$, which is equal, in line with Martins (2009), to the total revenues per workers minus non-labour costs and the alternative wage, where the total revenues per workers minus non-labour costs have been proxied by using accounting profits per workers plus total personnel costs per worker. ${ }^{13}$

The term I_Char ${ }_{i, t}$ is the set of observed individual characteristics, such as age, age squared, tenure (in three categories, 1-2, 3-10, more than 10 years) and occupation dummy (blue collar and white collar). $M W_{c(i, t)}$ is the national contract minimum wage. Firmsize $_{i, t}$ (in log) is the proxy for firm heterogeneity, while $\varphi_{s,} \lambda_{a}, \delta_{t}$ are industry (17 sectors), regional (20 regions) and year dummies respectively. All the relevant variables are in logarithms and therefore we estimate elasticities. Table 1 shows the descriptive statistics of the variables of the analysis.

[Table 1 around here] 
In the first specification, as benchmark estimates, we perform cross-sectional quantile estimates where, as already pointed out, we use as alternative wage the minimum wage which captures the extent of the first (national) level of bargaining. It is worth noting that the minimum wage turns out to be a very accurate measure to control for first level bargaining at the national level. At the same time it is an appropriate measure of the opportunity cost of labor. We prefer to use this measure, in contrast to the average industrial wages generally used in the literature, because it is related to the specific contract (and within the contract to the specific level) the worker belongs to. ${ }^{14}$ Nonetheless, in the following we will also carry out a robustness check using as measure for the opportunity cost of labour a standard average industrial wage.

Since an important concern in our analysis is to tackle the issue of the unobserved heterogeneity that can bias the cross sectional estimates, we then carry out quantile fixed effects estimates (Canay, 2011). In fact, in the literature unobserved worker heterogeneity has been proved to be very important in affecting the relationship between rents and wages since high-skilled workers may sort into highly profitable firms (Martins, 2009, Arai and Heyman, 2001, Margolis and Salvanes, 2001). Furthermore, recent papers have also taken into account firm unobserved heterogeneity that might play a crucial role in affecting firm profitability and rent sharing policies. Card et al. (2014) consider their preferred specification the one that includes job-match effect (i.e., fixed effects for each worker-firm pair) that control for unobserved heterogeneity of both workers and firms. We follow this empirical strategy approach using job-match fixed effects in all estimates presented in this paper.

Finally, in order to control also for the issue of the endogeneity between profits and wages (due to simultaneous determination and to possible measurements error) we apply an IV strategy. The literature has stressed that in case of endogeneity the (attenuation) bias in the cross-sectional estimates can be severe, and may also be aggravated by a fixed effects strategy (Card et al., 2014). Therefore, we use a very recently developed estimation strategy of IV quantile fixed effects estimates (Galvao, 2011, and Galvao and Montes-Rojas, 2010), which is an extension of the IV quantile procedure of Chernozukov and Hansen (2008) that allows for the inclusion of fixed effects as introduced in Koenker (2004). ${ }^{15}$ As instrument we exploit the idea developed in Card et al. (2014) by using a weighted average of the firm sales per employee in other provinces of Italy but in the same three-digit industry of the firm considered. The 
weights are the inverse of the distance between the main province cities ('capoluoghi'). The idea is that industry sales, which represent industry demand shocks, affect the profitability of the firms while, at the same time, they are not correlated with local labor market conditions since they concern firms in other provinces of Italy. Card et al. (2014) provide evidence supporting this identifying assumption. ${ }^{16}$ Since their analysis concerns the Italian labour market (using also the same administrative data even if only for the Veneto region), the same evidence can be used to support our analysis. Nonetheless, we carry out a robustness check concerning the exogeneity of our instrument. In particular, we address the issue that demand shocks in provinces within the same region of the province where the firm is located might be spatially correlated. For this reason, we will carry out our preferred estimates using an alternative definition for the instrument where we exclude from the instrument computation the provinces belonging to the same region where the firm is located.

\section{$4.2 \quad$ Results}

Table 2 shows the cross-sectional quantile estimates of the impact of profits per employee on workers' wages, by using the minimum wage as a measure for the opportunity cost of labor.

The main relevant variable, quasi-rent, displays a non-uniform impact along the wage distribution. In particular, elasticity estimates decrease along the wage distribution, standing at $5.4 \%$ at the $10^{\text {th }}$ percentile, $5.0 \%$ at the median and $4.3 \%$ at the $90^{\text {th }}$ percentile. The impact at the median is then very similar to that at the mean $5 \%$ (table A2 in the Appendix), which is not surprising since the distribution of (log) wages should come fairly close to a symmetric distribution. The Lester range associated to the OLS estimates is $13.7 \%$, slightly lower with respect to Card et al. (2010). ${ }^{17}$ Moreover, since these elasticities have been computed by controlling for the importance of the first (national) level of bargaining, they suggest that there is a non-negligible rent sharing that essentially takes place at the local, firm and individual level (consistently with Van Reenen, 1996). ${ }^{18}$

[Table 2 around here] 
The cross sectional standard quantile regressions are likely to be biased since they do not take into account the unobserved heterogeneity of workers and firms. Therefore we run quantile fixed effects estimates (Canay, 2011), enabling the introduction of jobmatch fixed effects in the estimation, in such a way as to capture time invariant worker and firm unobserved heterogeneity. Table 3 shows the results. The estimates change significantly: the coefficients are much reduced in magnitude and slightly decreasing along the wage distribution, ranging from $1.6 \%$ at the $10^{\text {th }}$ percentile to $1.3 \%$ at the $90^{\text {th }}$ percentile. ${ }^{19}$ For sake of comparison, in column 2 of Table A2 in the Appendix we also report the standard fixed effect estimation computed at the mean, that provides a coefficient actually equal to the one computed at the median.

[Table 3 around here]

These results are consistent with previous empirical evidence showing that taking into account the unobserved worker and firm heterogeneity entails a sharp reduction in the estimated degree of rent sharing (see Card et al., 2014, Martins, 2009).

Finally, we present the IV estimates to tackle the endogeneity between rents and wages; in fact, endogeneity can cause serious underestimation of the degree of rent sharing, which can also be worsened by a fixed effects strategy (Card et al., 2014). The estimation was carried out simultaneously on three percentiles $\left(10^{\text {th }}, 50^{\text {th }}, 90^{\text {th }}\right)$. Moreover, since it is not possible to test the weakness of the instrument in this procedure, we carried out a standard IV fixed effects estimation on average wages (see table A2 in the Appendix), checking the first stage F-statistics. The F-value for the instrument in the first stage is significant and higher than the threshold value of 10 , confirming that the instrument chosen is not weak.

When endogeneity is taken into account, the results change significantly (Table 4). In fact, the elasticities of rents with respect to wages are now greater, and the highest increases are to be seen in the lower tail of the wage distribution. In particular, rents show a decreasing impact along the wage distribution with elasticities ranging from $7.3 \%$ at the 10 th percentile to $6.1 \%$ at the median and $5.0 \%$ at the $90^{\text {th }}$ percentile, which are significantly different across wage percentiles. ${ }^{20}$ These estimates are quite consistent with those of Card et al. (2014), who find an elasticity of (average) wages with respect to rents of $4.5 \%$ for the Veneto region in Italy. 
[Table 4 around here]

This evidence suggests that once having controlled for the national centralized level of bargaining, unobserved heterogeneity and endogeneity, rent sharing in Italy is such as to favor the low paid workers.

We carry out a set of robustness checks of our preferred quantile IV fixed effect estimates. First, we carry out the IV estimation using an alternative definition of the instrument, where we exclude from its computation the sales in provinces belonging to the same region of the province where the firm is located, in order to avoid possible spatial correlation between provinces within the same region (Table A3). Second, as shown in Table A4 in the Appendix, we run the same estimates excluding part-time workers, in order to check whether our results are affected by the inclusion of parttime workers (converted into full-time equivalent workers) in the main estimation sample. Third, we run the same estimates using a different measure for the alternative wage (Table A5 in the Appendix). In particular, we employ a measure of average industrial wage carried out by averaging wages within industry-wide national contracts, separately for blue collars and white collars. ${ }^{21}$ Last, we perform the same estimates using a set of firm size dummies (defined on the basis of the deciles of the firm size distribution) in place of the logarithm of the firm size, to control for stronger nonlinearities in the relationship between the firm size and wages (Table A6 in the Appendix). Results of these robustness checks are strongly consistent with the baseline estimates. 22

\subsection{Occupation heterogeneity: Blue Collars versus White collars}

The literature so far has investigated the heterogeneity of rent sharing across groups of workers using differences in skills. Since education is not usually available in administrative data, this issue has been mainly addressed using differences in occupation levels, i.e. comparing blue collar and white collar workers. Our administrative data allows implementing the same approach, distinguishing between blue and white collar workers.

Apart from replicating what already done in the literature, i.e. carrying out our

preferred specification separately for the two groups of workers using standard 
regressions at the conditional mean (Table A2), we apply the quantile regressions approach to the two groups of workers, in order to investigate the heterogeneity in rent sharing within the two occupational categories for workers located at different percentiles of the wage distribution. We do believe this represent an additional contribution to the literature, since it extends the standard sample split by occupation to a quantile regression approach. This approach is of interest because of the important differences at work within occupational categories in terms of earnings. ${ }^{23}$

We apply our preferred specification, controlling for unobserved worker and firm heterogeneity and for endogeneity, to the samples of blue collar and white collar workers. Results are reported in Table 5. Interestingly, patterns are rather different for the two groups of workers. For blue collars, the extent of rent sharing is still decreasing along the wage distribution, with an elasticity that runs from $3.4 \%$ at the $10^{\text {th }}$ percentile to a not statistically significant elasticity at the $90^{\text {th }}$ percentile. For white collar workers, the coefficients are higher (around 26\%), and basically constant across the distribution. This is consistent with the findings in other papers, such as Arai and Heyman (2001), who find higher rent sharing for white collar workers, and Martins (2009) and Guertzgen (2009) who provide evidence of higher rent sharing for better educated workers, with the underlying intuition that high skilled workers might have higher power in the individual bargaining. ${ }^{24}$ In the next section we will further explore this issue.

[Table 5 around here]

\subsection{Possible explanation: The role of unions}

We have shown that the impact of rent sharing is decreasing along the wage distribution and that this decreasing pattern is driven by the blue collars dynamics, while white collars enjoy a higher and stable pattern of rent sharing along the wage distribution. Two possible explanations for these findings might be at work. The first one concerns the role of unions that might foster workers' wages, especially for the unskilled workers (Card, 1996), while the second one focuses on the role of individual bargaining. Both explanations could have a different incidence for blue collars and while collars and also, within the two occupational groups, for different percentiles of their wage distribution. Unfortunately, we cannot rigorously test these two explanations, because of data limitations. In fact, our administrative data do not 
include a reliable proxy for the role of individual bargaining in the wage setting process within the firm, i.e. there is not availability of any information about wage policies at the firm level and on the role of individual bargaining. Similarly, we do not know whether a given firm is unionized, i.e., if there is a legal entity that is allowed to bargain with the employer.

Nonetheless, a partial test we can carry out concerns the possibility to use another source of data to investigate the role of unions. ${ }^{25}$ In particular, we focus on manufacturing, since the literature has shown that the unions in this sector can be assumed to be more organized and with greater power (see for instance Booth, 1995, Disney, 1990)..26 Further, we exploit the information on unionized firms coming from the dataset "Rilevazione su Imprese e Lavoro -RIL" (Surveys on Firms and workers) elaborated by ISFOL for the year 2005.27 This dataset allows identifying unionized firms, i.e. those firms characterized by any form of workers' representation at the workplace that is legally entitled to participate in the firm-level bargaining process. Using this information we compute the share of unionized firms at the region-industry level in the manufacturing sector (20 regions and 9 sectors within manufacturing), taking into account firms with at least 15 employees (consistently with INPS-AIDA data) and region-industry cells with at least 10 firms in order to get reliable values for the union share variable. ${ }^{28}$ We then split the sample on the basis of the share of unionized firms, which can be considered as a proxy of regional-sectoral union power. More specifically, we derive a dummy equal to one if in a given region-industry cell the share of unionized firms is greater than the overall median value. We finally adapt our preferred specification interacting the quasi-rent variable with the union dummy.

An important premise of this analysis is the fact that we consider union as an exogenous variable. This might not be the case. However, it is well-known that it is hard to find an exogenous variation in unions, especially in European countries. ${ }^{29}$ Nonetheless, Breda (2015), focusing on France, argues that, conditional on observable characteristics, it is not necessarily the case that workplace unionization systematically targets more profitable/efficient/better firms. This is mainly due to the fact that it is typically very easy to organize a firm's workers in a union, since what is needed is only to find a worker who is willing to act as union representative, or to contact the local union officials who are always willing to help on how to set up a union in a firm. In such an institutional environment, Breda (2015) assumes that that estimates are unlikely to be biased by a selection of the best firms by unions, and hence that the 
assignment to treatment can be assumed as 'quasi-random'. The Italian institutional framework is very similar to the French one, thus supporting the choice of considering union as exogenous when applying a similar approach, i.e. using a wide and accurate set of controls in the empirical analysis.

Table 6 reproduces our baseline estimates, i.e., without the interaction with the union dummy, for blue collars and white collars for the manufacturing sector, which represents the sector of interest for the analysis of unions, to check whether when focusing on this sector previous findings change. Results show a similar pattern with respect to those derived for the whole economy (Table 5). The blue collar coefficients are, as expected, slightly higher, while the white collar coefficients are significantly lower, suggesting that rent sharing for white collar workers is higher in the service sector (consistently with Arai and Heyman, 2001). In particular, elasticities in the manufacturing sector decrease from $6.0 \%$ at the 10 th percentile to a non-significant $0.006 \%$ at the 90 th percentile for blue collars, while they are around $10 / 12 \%$ for white collars over the whole wage distribution. ${ }^{30}$

[Table 6 around here]

Table 7 shows the rent-sharing estimations, for blue collars and white collars, with the introduction of the interaction term between the quasi-rent variable and the union dummy. As for blue collars, results show that the interaction between quasi-rents and unions is positive and statistically significant along the whole wage distribution, with a decreasing pattern that runs from $14.7 \%$ at the 10 th percentile to $7 / 8 \%$ at the 50 th $/ 90$ th percentiles. Moreover, the baseline effects of rent sharing are negligible, suggesting that where union power is low the rent sharing for blue collars almost disappears. As for white collars, the interaction with the union dummy is positive and significant up to the 50th percentile (around 12\%), while at the 90th percentile the elasticity is lower and not statistically different from zero. On the other hand, the baseline effects are positive and increasing along the wage distribution (up to $3 \%$ at the 90 th percentile) suggesting that the pattern previously detected for white collar workers might be explained by two main drivers: unions play a major role at the low and middle part of the wage distribution, while individual bargaining seems to matter more for the medium and high skilled workers. ${ }^{31}$ Of course, this way of reasoning assumes that 
once we control for observed and unobserved individual and firm heterogeneity, national bargaining, endogeneity and the power of local unions, the residual rent sharing can be interpreted as the impact of individual bargaining.

This evidence confirms the intuition that labor market institutions, and in particular the unions, contribute, at least in part, to the heterogeneous extent of rent sharing along the wage distribution, suggesting that unions favor rent sharing for low and medium skilled workers. The underline intuition of this result that, to the best of our knowledge, represents an original empirical finding within the rent sharing literature, is consistent with a robust empirical evidence on the distributional goal of unions, which mainly take care of the welfare on unskilled workers (Di Nardo et al., 1996; Card, 1996; Frandsen, 2012).

Nonetheless, we want to point out that the findings of this section have to be taken with cautious because of the assumption of union exogeneity and the lack of a firm measure of unionization that forced us to make use of a regional-sectoral measure. Beyond these drawbacks, we believe the section provides interesting evidence on the possible explanations behind the baseline results.

\section{[Table 7 around here]}

\section{Conclusions}

The contribution of this paper is to analyze the degree of rent sharing along the wage distribution. Previous empirical analyses focused only on average wages. In some cases attention have been paid to average wages of workers' groups defined using education and/or occupation categories, which however does not allow taking into account the substantial heterogeneity within workers' groups. In this paper we address this issue by using quantile regressions, since percentiles of the wage distribution can be more closely associated to the productivity of workers in the labor market.

We make use of a unique employer-employee database for Italy, which merges administrative records for workers (INPS) and balance sheet data for firms (AIDA). Our findings show that the rent sharing impact is not uniform along the wage distribution. In particular, taking into account the first national level of bargaining, unobserved worker and firm heterogeneity and endogeneity, we find a decreasing pattern of rent sharing along the wage distribution, with elasticities of wages with 
respect to quasi-rents ranging from $7.3 \%$ at the 10 th percentile to $5.0 \%$ at the 90 th percentile of the wage distribution.

In the paper we also integrate the quantile regressions approach with the standard approach using sample split by occupation categories. More specifically, we apply quantile regressions for the two groups of blue and white collar workers in order to capture the heterogeneity within occupation categories that cannot be taken into account using the traditional sample split analysis at the conditional mean. Interestingly, we find out that the decreasing pattern of rent sharing previously detected is driven by the dynamics for blue collar workers, while white collars enjoy a stable and higher degree of rent sharing along the wage distribution.

One of the possible explanations for these findings refers to the role of the unions, which in Italy play a crucial role in the bargaining process between employers and employees. We provide evidence in favor of this possible explanation exploiting the regional and sectoral variability in the share of unionized firms, which can be considered as a proxy for union power. We show that where union power is high the extent of rent sharing for blue collar is still decreasing and mainly driven by unions, while little is left to individual bargaining. As for white collars, unions play a major role at the low and middle part of the wage distribution, while individual bargaining seems to be at work for the high skilled workers.

Nonetheless, these findings on the role of unions have to be taken with cautious because of the assumption of the exogeneity of unions (Breda, 2015) and the use of an imperfect proxy of union power. Hence, future research is needed to shed light on the underlying mechanisms driving our results, by using different and more qualitative survey data on unions and firms strategies which might allow overcoming the limitations due to the use of administrative data. 


\section{References}

Abowd, J. and Lemieux, T. (1993). 'The effects of Product Market Competition on Collective Bargaining Agreements: The case of Foreign Competition in Canada', Quarterly Journal of Economics, 108: 983-1014.

Arai, M. (2003). 'Wages, Profits and Capital Intensity: Evidence from Matched WorkerFirm Data', Journal of Labor Economics, 21: 593-618.

Arai, M. and Heyman, F. (2001). 'Wages, profits and individual unemployment risk: evidence from matched firm-worker data', FIEF Working Paper series, 172.

Bartolucci, C., Devicienti, F. and Monzon, I. (2015). 'Identifying Sorting in Practice', IZA Discussion Paper, 9411.

Blanchflower, D., Oswald A. and Sanfey, P. (1996). 'Wages, Profits and Rent Sharing', Quarterly Journal of Economics, 111: 227-252.

Booth, A. (1995). The Economics of Trade Unions, Cambridge University Press.

Breda, T. (2015). 'Firms' rents, workers' bargaining power and the union wage premium in France', Economic Journal, 125(589): 1616-1652.

Canay, I. (2011). 'A Simple Approach to Quantile Regression for Panel Data', The Econometrics Journal, 14(3): 368-386.

Card, D. (1996). 'The Effect of Unions on the Structure of Wages: A Longitudinal Analysis', Econometrica, 64: 957-979.

Card, D., Devicienti, F. and Maida, A. (2010). 'Rent Sharing, Hold Up and Wages: Evidence from Matched Panel Data', NBER Working Paper, 16192.

Card, D., Devicienti F. and Maida A. (2014). 'Rent Sharing, Hold Up and Wages: Evidence from Matched Panel Data', The Review of Economic Studies, 81(1): 84-111.

Chernozukov, V. and Hansen C., (2008). 'Instrumental Variable Quantile Regression: A Robust Inference Approach', Journal of Econometrics, 142: 379-398.

Di Nardo, J., Fortin, N.M. and Lemieux, T. (1996). 'Labor Market Institutions and the Distribution of Wages, 1973-1992: A Semiparametric Approach', Econometrica, 64: 1001-1044.

Di Nardo, J. and Lee, D.S. (2004). 'Economic Impacts of New Unionization on Private Sector Employers: 1984-2001', Quarterly Journal of Economics, 119(4): 1383-1441. 
Disney, R. (1990). 'Explanations of the Decline in Trade Union Density In Britain: an Appraisal', British Journal of Industrial Relations, 28(2): 165-177.

Frandsen, B. R. (2012). 'Why Unions Still Matter: The Effects of Unionization on the Distribution of Employee Earnings', (Manuscript). Cambridge, MA: Massachusetts Institute of Technology.

Galvao, A. (2011). 'Quantile Regression for Dynamic Panel Data with Fixed Effects', Journal of Econometrics, 164: 142-157.

Galvao, A. and Montes-Rojas, G. (2010). 'Penalized Quantile Regression for Dynamic Panel Data', Journal of Statistical Planning and Inference, 140: 3476-3497.

Guertzgen, N. (2009). 'Rent-Sharing and Collective Bargaining Coverage - Evidence from Linked Employer-Employee Data', Scandinavian Journal of Economics, 111(2): 323-349.

Hildreth, A. and Oswald, A. (1997). 'Rent Sharing and Wages: Evidence from Company and Establishment Panels', Journal of Labor Economics, 15: 318-337.

Koenker, R. and Bassett, G. (1978). ‘Regression Quantiles', Econometrica, 46(1): 33-50.

Koenker, R. (2004). 'Quantile Regression for Longitudinal Data', Journal of Multivariate Analysis, 91: 74-89.

Krueger, A.B. and Summers, L.H. (1988). 'Efficiency Wages and the Inter-Industry Wage Structure', Econometrica, 56(2): 259-293.

Lee, D. and Mas, A. (2012). 'Long-Runs Impacts of Unions on Firms: New Evidence from Financial Markets, 1961-1999', The Quarterly Journal of Economics, 127(1): 333378.

Lemieux, T., MacLeod, B. and Parent, D. (2009). 'Performance Pay and Wage Inequality', Quarterly Journal of Economics, 124(1): 1-49.

Lester, R.A. (1952). 'A Range Theory of Wage Differentials', Industrial and Labor Relations Review, 5: 483-500.

Margolis, D. and Salvanes, K. (2001). 'Do Firms Really Share Rents with Their Workers?', IZA Discussion Paper, 330.

Martins, P.S. (2007). 'Rent Sharing and Wages', Reflets et Perspectives de la Vie Economique, 46(2): 23-31.

Martins, P.S. (2009). 'Rent Sharing Before and After the Wage Bill', Applied Economics, 41(17): 2133-2151. 
Matano, A. and Naticchioni, P. (2012). 'Wage Distribution and the Spatial Sorting of Workers', Journal of Economic Geography, 12(2): 379-408.

Matano, A. and Naticchioni, P. (2013). 'Rent Sharing as a Driver of the Glass Ceiling Effect', Economic Letters, 118(1): 55-59.

Nickell, S.J. (1981). 'Biases in Dynamic Models with Fixed Effects', Econometrica, 49: 1417-1426.

Rusinek, M. and Rycx, F. (2013). 'Rent-Sharing under Different Bargaining Regimes: Evidence from Linked Employer-Employee Data', British Journal of Industrial Relations, 51(1): 28-58.

Shapiro, C. and Stiglitz, J. (1984). 'Equilibrium Unemployment as a Worker Discipline Device', American Economic Review, 74: 433-444.

Van Reenen, J. (1996). 'The Creation and Capture of Rents: Wages and Innovation in a Panel of U.K. Companies', Quarterly Journal of Economics, 111: 195-226. 
Tables

\begin{tabular}{|c|c|c|c|c|}
\hline Variable & Mean & Std. Dev. & Min & Max \\
\hline Log Real Weekly Wage & 5.99 & 0.30 & 4.96 & 7.04 \\
\hline Log Real Weekly Minimum Wage & 5.69 & 0.11 & 4.96 & 6.77 \\
\hline Female & 0.32 & 0.46 & 0.00 & 1.00 \\
\hline Age & 36.79 & 9.74 & 15 & 70 \\
\hline Age Squared & $1,448.28$ & 755.97 & 225 & 4,900 \\
\hline Blue Collars & 0.65 & 0.48 & 0 & 1 \\
\hline White Collars and Manager & 0.35 & 0.48 & 0 & 1 \\
\hline Log Firm Size & 4.62 & 1.25 & 2.708 & 9.01 \\
\hline Log Quasi-Rent per Employee & 3.01 & 0.76 & -7.56 & 5.07 \\
\hline $\begin{array}{l}\text { Log Real Sales per Employee other } \\
\text { provinces (instrument) }\end{array}$ & 5.24 & 0.52 & 2.17 & 7.64 \\
\hline Tenure 1-2 & 0.31 & 0.46 & 0 & 1 \\
\hline Tenure 3-10 & 0.51 & 0.50 & 0 & 1 \\
\hline Tenure $>10$ & 0.19 & 0.39 & 0 & 1 \\
\hline North East & 0.31 & 0.46 & 0 & 1 \\
\hline North West & 0.43 & 0.49 & 0 & 1 \\
\hline Centre & 0.16 & 0.36 & 0 & 1 \\
\hline South & 0.09 & 0.28 & 0 & 1 \\
\hline Island & 0.03 & 0.16 & 0 & 1 \\
\hline By Percentiles & 10th & 50th & 90th & \\
\hline Log Real Weekly Wage & 5.66 & 5.94 & 6.39 & \\
\hline Log Real Weekly Minimum Wage & 5.56 & 5.66 & 5.84 & \\
\hline Number of Observations & 157,600 & & & \\
\hline Number of Workers & 38,810 & & & \\
\hline Number of Job Matches & 41,965 & & & \\
\hline
\end{tabular}

Source: Panel ISFOL on INPS-AIDA data. 


\begin{tabular}{|c|c|c|c|c|c|}
\hline & q10 & $\mathrm{q} 25$ & q50 & q75 & q90 \\
\hline Ln Quasi Rent & $0.054^{* * *}$ & $0.051^{* * *}$ & $0.050^{* * *}$ & $0.046^{* * *}$ & $0.043^{* * *}$ \\
\hline Ln Minimum Wage & $1.465^{* * *}$ & $1.555^{* * *}$ & $1.663^{* * *}$ & $1.761^{* * *}$ & $1.791^{* * *}$ \\
\hline Gender Dummy & $-0.070^{* * *}$ & $-0.071^{* * *}$ & $-0.090^{* * *}$ & $-0.119 * * *$ & $-0.155^{* * *}$ \\
\hline Age & $0.010^{* * *}$ & $0.009^{* * *}$ & $0.009^{* * *}$ & $0.008^{* * *}$ & $0.008^{* * *}$ \\
\hline Age Squared & $-0.000 * * *$ & $-0.000^{* * *}$ & $-0.000^{* * *}$ & $-0.000^{* * *}$ & $-0.000^{* * *}$ \\
\hline Tenure 3-10 & $0.038^{* * *}$ & $0.029^{* * *}$ & $0.020^{* * *}$ & $0.012^{* * *}$ & $0.008^{* * *}$ \\
\hline Tenure $>10$ & $0.071^{* * *}$ & $0.053^{* * *}$ & $0.036^{* * *}$ & $0.025^{* * *}$ & $0.018^{* * *}$ \\
\hline White Collar Dummy & $0.040^{* * *}$ & $0.040^{* * *}$ & $0.053^{* * *}$ & $0.073^{* * *}$ & $0.104^{* * *}$ \\
\hline In Firm Size & $0.019^{* * *}$ & $0.019 * * *$ & $0.017^{* * *}$ & $0.014^{* * *}$ & $0.009^{* *}$ \\
\hline Const & $-3.129 * * *$ & $-3.557^{* * *}$ & $-4.123^{* * *}$ & $-4.607^{* * *}$ & $-4.384^{* * *}$ \\
\hline $\begin{array}{l}\text { Region, Time and Sector } \\
\text { dummies }\end{array}$ & yes & yes & yes & yes & yes \\
\hline N. Observations & 157,600 & 157,600 & 157,600 & 157,600 & 157,600 \\
\hline N. Job Matches & 41,965 & 41,965 & 41,965 & 41,965 & 41,965 \\
\hline
\end{tabular}

Notes: ${ }^{* * *}, * *$ and ${ }^{*}$ denote significance at $1 \%, 5 \%$ and $10 \%$ respectevely. 


\begin{tabular}{|c|c|c|c|c|c|}
\hline & q10 & $\mathrm{q} 25$ & q50 & q75 & $\mathrm{q} 90$ \\
\hline Ln Quasi Rent & $0.016^{* * *}$ & $0.013^{* * *}$ & $0.013^{* * *}$ & $0.013^{* * *}$ & $0.013^{* * *}$ \\
\hline Ln Minimum Wage & $0.849^{* * *}$ & $0.835^{* * *}$ & $0.837^{* * *}$ & $0.840^{* * *}$ & $0.837^{* * *}$ \\
\hline Age & $0.033^{* * *}$ & $0.030^{* * *}$ & $0.028^{* * *}$ & $0.026^{* * *}$ & $0.023^{* * *}$ \\
\hline Age Squared & $-0.000^{* * *}$ & $-0.000^{* * *}$ & $-0.000 * * *$ & $-0.000^{* * *}$ & $-0.000^{* * *}$ \\
\hline Tenure 3-10 & $0.020^{* * *}$ & $0.013^{* * *}$ & $0.007 * * *$ & $0.003^{* * *}$ & 0.001 \\
\hline Tenure $>10$ & $0.014^{* * *}$ & $0.006^{* * *}$ & 0.000 & $-0.004^{* * *}$ & $-0.009^{* * *}$ \\
\hline White Collar Dummy & $0.035^{* * *}$ & $0.038^{* * *}$ & $0.037^{* * *}$ & $0.037^{* * *}$ & $0.044^{* * *}$ \\
\hline ln Firm Size & $0.031^{* * *}$ & $0.030^{* * *}$ & $0.030 * * *$ & $0.029 * * *$ & $0.029 * * *$ \\
\hline Const & $0.071^{* *}$ & $0.275^{* * *}$ & $0.345^{* * *}$ & $0.399 * * *$ & $0.517^{* * *}$ \\
\hline $\begin{array}{l}\text { Region, Time and Sector } \\
\text { dummies }\end{array}$ & yes & yes & yes & yes & yes \\
\hline N. Observations & 157,600 & 157,600 & 157,600 & 157,600 & 157,600 \\
\hline N. Job Matches & 41,965 & 41,965 & 41,965 & 41,965 & 41,965 \\
\hline
\end{tabular}

Notes: ${ }^{* * * * *}$ and * denote significance at $1 \%, 5 \%$ and $10 \%$ respectevely. 


\begin{tabular}{l|lll}
\hline Table 4: Quantile IV Fixed Effects Regressions of Wages on Quasi Rents. \\
\hline & q10 & q50 & q90 \\
\hline Ln Quasi Rent & $0.073^{* * *}$ & $0.061^{* * *}$ & $0.050^{* * *}$ \\
Ln Minimum Wage & $0.849^{* * *}$ & $0.840^{* * *}$ & $0.862^{* * *}$ \\
\hline Age & $0.039^{* * *}$ & $0.036^{* * *}$ & $0.030^{* * *}$ \\
Age Squared & $-0.000^{* * *}$ & $-0.000^{* * *}$ & $-0.000^{* * *}$ \\
Tenure 3-10 & $0.025^{* * *}$ & $0.007^{* * *}$ & -0.001 \\
Tenure >10 & $0.019^{* * *}$ & $0.003^{* * *}$ & $-0.010^{* * *}$ \\
White Collar Dummy & $0.029^{* * *}$ & $0.030^{* * *}$ & $0.038^{* * *}$ \\
ln Firm Size & $0.051^{* * *}$ & $0.051^{* * *}$ & $0.051^{* * *}$ \\
Const & $3.100^{* * *}$ & $3.329^{* * *}$ & $3.393^{* * *}$ \\
\hline $\begin{array}{l}\text { Region, Time and Sector dummies } \\
\text { N. Observations }\end{array}$ & $\begin{array}{l}\text { yes } \\
\text { N. Job Matches }\end{array}$ & $\begin{array}{l}\text { yes } \\
157,600\end{array}$ & $\begin{array}{l}\text { yes } \\
1,600\end{array}$ \\
\hline \hline
\end{tabular}

Notes: ${ }^{* * *}, * *$ and $*$ denote significance at $1 \%, 5 \%$ and $10 \%$ respectevely.

\begin{tabular}{|c|c|c|c|c|c|c|}
\hline & \multicolumn{3}{|c|}{ Blue Collars } & \multicolumn{3}{|c|}{ White Collars } \\
\hline & q10 & q50 & q90 & q10 & q50 & q90 \\
\hline Ln Quasi Rent & $0.034^{* * *}$ & $0.012^{* * *}$ & 0.001 & $0.266^{* * *}$ & $0.264^{* * *}$ & $0.275^{* * *}$ \\
\hline Ln Minimum Wage & $0.737^{* * *}$ & $0.716^{\star * *}$ & $0.741^{* * *}$ & $0.944^{* * *}$ & $0.984^{* * *}$ & $1.023^{* * *}$ \\
\hline Age & $0.043^{* * *}$ & $0.038^{* * *}$ & $0.033^{* * *}$ & $0.032^{* * *}$ & $0.030^{* * *}$ & $0.026^{* * *}$ \\
\hline Age Squared & $-0.000^{* * *}$ & $-0.000^{* * *}$ & $-0.000^{* * *}$ & $-0.000^{* * *}$ & $-0.000^{* * *}$ & $-0.000^{* * *}$ \\
\hline Tenure 3-10 & $0.020^{* * *}$ & $0.005^{* * *}$ & $-0.005^{\star *}$ & $0.027^{* * *}$ & $0.011^{* * *}$ & $0.015^{* * *}$ \\
\hline Tenure $>\mathbf{1 0}$ & $0.015^{* * *}$ & $0.003^{* *}$ & $-0.010^{* * *}$ & $0.014^{* * *}$ & $0.004^{*}$ & -0.001 \\
\hline In Firm Size & $0.029^{* * *}$ & $0.029^{* * *}$ & $0.029^{* * *}$ & $0.134^{* * *}$ & $0.130^{* * *}$ & $0.131^{* * *}$ \\
\hline Const & $3.351^{* * *}$ & $3.705^{* * *}$ & $3.778^{* * *}$ & $3.156^{* * *}$ & $3.146^{* * *}$ & $3.055^{* * *}$ \\
\hline Region, Time and Sector dummies & yes & yes & yes & yes & yes & yes \\
\hline N. Observations & 102,076 & 102,076 & 102,076 & 54,812 & 54,812 & 54,812 \\
\hline N. Job Matches & 27,121 & 27,121 & 27,121 & 15,058 & 15,058 & 15,058 \\
\hline
\end{tabular}

Notes: ***,** and * denote significance at $1 \%, 5 \%$ and $10 \%$ respectevely. 


\begin{tabular}{|c|c|c|c|c|c|c|}
\hline & \multicolumn{3}{|c|}{ Blue Collars } & \multicolumn{3}{|c|}{ White Collars } \\
\hline & q10 & q50 & $\mathrm{q} 90$ & q10 & q50 & q90 \\
\hline Ln Quasi Rent & $0.060^{* * *}$ & $0.040^{* * *}$ & 0.006 & $0.102^{* * *}$ & $0.123^{* * *}$ & $0.107^{* * *}$ \\
\hline Ln Minimum Wage & $0.877^{* * *}$ & $0.842^{* * *}$ & $0.887^{* * *}$ & $0.798^{* * *}$ & $0.831^{* * *}$ & $0.858^{* * *}$ \\
\hline Age & $0.038^{* * *}$ & $0.034^{* * *}$ & $0.029^{* * *}$ & $0.050^{* * *}$ & $0.047^{* * *}$ & $0.043^{* * *}$ \\
\hline Age Squared & $-0.000^{* * *}$ & $-0.000^{* * *}$ & $-0.000^{* * *}$ & $-0.000^{* * *}$ & $-0.000^{* * *}$ & $-0.000^{* * *}$ \\
\hline Tenure 3-10 & $0.017^{* * *}$ & $0.004^{* * *}$ & $-0.008^{* * *}$ & $0.025^{* * *}$ & $0.009^{* * *}$ & $0.018^{* * *}$ \\
\hline Tenure $>10$ & $0.017^{* * *}$ & $0.0036^{* * *}$ & $-0.011^{* * *}$ & $0.014^{* * *}$ & 0.001 & 0.0000 \\
\hline In Firm Size & $0.037^{* * *}$ & $0.038^{* * *}$ & $0.039^{* * *}$ & $0.076^{* * *}$ & $0.073^{* * *}$ & $0.076^{* * *}$ \\
\hline Const & $2.687^{* * *}$ & $3.114^{* * *}$ & $3.145^{* * *}$ & $1.109^{* * *}$ & $1.041^{* * *}$ & $1.101^{* * *}$ \\
\hline Region, Time and Sector dummies & yes & yes & yes & yes & yes & yes \\
\hline N. Observations & 79,471 & 79,471 & 79,471 & 29,256 & 29,256 & 29,256 \\
\hline N. Job Matches & 20,255 & 20,255 & 20,255 & 7,684 & 7,684 & 7,684 \\
\hline
\end{tabular}

Notes: ${ }^{* *, * *}$ and ${ }^{*}$ denote significance at $1 \%, 5 \%$ and $10 \%$ respectevely.

\begin{tabular}{|c|c|c|c|c|c|c|}
\hline \multicolumn{7}{|l|}{$\begin{array}{l}\text { Table 7: Quantile IV Fix } \\
\text { Interaction with Union }\end{array}$} \\
\hline & q10 & q50 & $\mathrm{q} 90$ & q10 & q50 & $\mathrm{q} 90$ \\
\hline Ln Quasi Rent & $0.010^{* * *}$ & $0.012^{* *}$ & 0.002 & 0.012 & $0.026^{* *}$ & $0.030^{* *}$ \\
\hline Ln Quasi Rent * High Union & $0.147^{* * *}$ & $0.067^{* * *}$ & $0.082^{* * *}$ & $0.123^{* * *}$ & $0.120^{* * *}$ & 0.057 \\
\hline High Union & $-0.472^{* * *}$ & $-0.192^{* * *}$ & $-0.242^{* * *}$ & $-0.401^{* * *}$ & $-0.375^{* * *}$ & -0.177 \\
\hline Ln Minimum Wage & $0.944^{* * *}$ & $0.885^{* * *}$ & $0.807^{* * *}$ & $0.786^{* * *}$ & $0.807^{* * *}$ & $0.743^{* * *}$ \\
\hline Age & $0.040^{* * *}$ & $0.034^{* * *}$ & $0.024^{* * *}$ & $0.064^{* * *}$ & $0.048^{* * *}$ & $0.036^{* * *}$ \\
\hline Age Squared & $-0.000^{* * *}$ & $-0.000^{* * *}$ & $-0.000^{* * *}$ & $-0.000^{* * *}$ & $-0.000^{* * * *}$ & $-0.000^{* * *}$ \\
\hline Tenure $3-10$ & $0.008^{* * *}$ & $0.004^{* * *}$ & -0.002 & $0.013^{* * *}$ & $0.012^{* * *}$ & $0.008^{* * *}$ \\
\hline Tenure $>10$ & $0.004^{* * *}$ & $0.002^{*}$ & -0.002 & $0.007^{* * *}$ & $0.004^{* * *}$ & 0.001 \\
\hline In Firm Size & $0.056^{* * *}$ & $0.042^{* * *}$ & $0.033^{* * *}$ & $0.053^{* * *}$ & $0.054^{* * *}$ & $0.035^{\star * *}$ \\
\hline Const & $0.687^{* * *}$ & $2.519^{* * *}$ & $2.491^{* * *}$ & $1.071^{* * *}$ & $1.243^{* * *}$ & $2.284^{\star * *}$ \\
\hline Region, Time and Sector dummies & yes & yes & yes & yes & yes & yes \\
\hline N. Observations & 65,651 & 65,651 & 65,651 & 24,649 & 24,649 & 24,649 \\
\hline N. Job Matches & 16,612 & 16,612 & 16,612 & 6,413 & 6,413 & 6,413 \\
\hline
\end{tabular}

Notes: ${ }^{* * *, * *}$ and ${ }^{*}$ denote significance at $1 \%, 5 \%$ and $10 \%$ respectevely. 


\section{Appendix}

\begin{tabular}{|c|c|c|c|c|c|}
\hline & $\begin{array}{c}\text { Universe of Job- } \\
\text { Year Observations } \\
\text { (1) }\end{array}$ & $\begin{array}{c}\text { Matched } \\
\text { Job-Year } \\
\text { Observations } \\
\text { (2) }\end{array}$ & $\begin{array}{c}\text { Panel } \\
\text { Estimation } \\
\text { Sample } \\
\text { (3) }\end{array}$ & $\begin{array}{l}\text { Subset with } \\
\text { Minimum } \\
\text { Wage } \\
\text { (4) }\end{array}$ & $\begin{array}{c}\text { Subset with at } \\
\text { least a spell of } \\
\text { two years } \\
\text { (5) }\end{array}$ \\
\hline Number of Workers & 196,485 & 121,709 & 75,804 & 58,793 & 38,810 \\
\hline Real Weekly Wage & 397.18 & 423.17 & 405.88 & 410.90 & 416.62 \\
\hline \multirow[t]{2}{*}{ Real Weekly Minimum Wage } & 288.04 & 295.88 & 295.06 & 295.06 & 296.57 \\
\hline & missings $(270,805)$ & nissings $(123,466)$ & nissings $(61,771)$ & & \\
\hline Age & 36.51 & 36.877 & 36.59 & 36.339 & 36.79 \\
\hline Females & 0.37 & 0.34 & 0.33 & 0.32 & 0.32 \\
\hline White Collars & 0.37 & 0.38 & 0.34 & 0.35 & 0.35 \\
\hline Number of Firms & 178,584 & 64,677 & 39,772 & 31,631 & 22,145 \\
\hline Firm Size (INPS) & 68 & 124 & 99 & 99 & 100 \\
\hline Firm Size (AIDA) & & 155 & 101 & 101 & 101 \\
\hline Quasi Rent per Employee (1000s euro) & & 38.97 & 25.12 & 25.78 & 25.62 \\
\hline Quasi Rent per Employee (1000s euro) Median & & 19.53 & 21.20 & 21.79 & 21.72 \\
\hline Real Sales per Employee (1000s euro) & & 297.48 & 210.75 & 223.55 & 226.44 \\
\hline Number of Records & 963,763 & 483,867 & 249,376 & 187,605 & 157,600 \\
\hline Number of Job Matches & & & 92,612 & 70,199 & 41,965 \\
\hline Mean Duration of Job Spell (years) & 4.7 & 4.4 & 4.2 & 4.1 & 4.7 \\
\hline \multicolumn{6}{|c|}{$\begin{array}{l}\text { The Universe of Job-Year Observations refers to the original INPS panel database, with workers aged between } 15 \text { and } 64 \text {, employed in standard labour } \\
\text { contracts (blue collars and white collars) and working in the industry and service sectors. The Matched Job-Year observations refer to the fraction of the } \\
\text { INPS panel database which has been merged with the AIDA database (with no any outlier and missing cleaning). The Panel Estimation Sample has been } \\
\text { costructed by dropping from the INPS-AIDA matched database the outliers in the firm size (observations for which the difference in absolute value between } \\
\text { the firm size reported in AIDA and the firm size reported in INPS was higher than 100) and missing observations for the variables of interest. Further, the } \\
\text { "construction" and "mining" sectors were excluded as well as firms with less than } 15 \text { employees. Finally, extreme observations below (above) the } 1 \text { st ( } 99 \text { th) } \\
\text { percentile of wages, profits per employee and total personnel costs variables were dropped from the sample. The Subset with Minimum Wage referes to the } \\
\text { fraction of the Panel Estimation Sample for which there is the availability of the minimum wage. The subset with at least a spell of two years, considers the }\end{array}$} \\
\hline
\end{tabular}


Table A2: OLS Regressions of Average Wages on Quasi Rents.

\begin{tabular}{|c|c|c|c|c|c|}
\hline & Cross Section & Fixed Effects & $\begin{array}{l}\text { IV-Fixed Effects } \\
\text { All }\end{array}$ & $\begin{array}{l}\text { IV-Fixed Effects } \\
\text { Blue Collars }\end{array}$ & $\begin{array}{l}\text { IV-Fixed Effects } \\
\text { White Collars }\end{array}$ \\
\hline Ln Quasi Rent & $0.050^{* * *}$ & $0.013^{* * *}$ & $0.072^{* * *}$ & 0.012 & $0.259^{* * *}$ \\
\hline Ln Minimum Wage & $1.623^{* * *}$ & $0.841^{* * *}$ & $0.884^{* * *}$ & $0.702^{* * *}$ & $0.994^{* * *}$ \\
\hline Female Dummy & $-0.106^{* * *}$ & & & & \\
\hline Age & $0.010^{* * *}$ & $0.028^{* * *}$ & $0.026^{* * *}$ & $0.022^{* * *}$ & $0.036^{* * *}$ \\
\hline Age Squared & $-0.000^{* * *}$ & $-0.000^{* * *}$ & $-0.000^{* * *}$ & $-0.000^{* * *}$ & $-0.000^{* * *}$ \\
\hline Tenure 3-10 & $0.024^{* * *}$ & $0.010^{* * *}$ & $0.009^{* * *}$ & $0.006^{* * *}$ & $0.018^{* * *}$ \\
\hline Tenure $>10$ & $0.042^{* * *}$ & 0.002 & 0.002 & 0.0000 & $0.010^{* *}$ \\
\hline White Collar Dummy & $0.071^{* * *}$ & $0.038^{* * *}$ & $0.037^{* * *}$ & - & - \\
\hline In Firm Size & $0.015^{\star *}$ & $0.030^{* * *}$ & $0.052^{* * *}$ & $0.023^{* * *}$ & $0.126^{* * *}$ \\
\hline Const & $-3.720^{* * *}$ & $0.254^{* *}$ & & & \\
\hline Region, Time and Sector dummies & yes & yes & yes & yes & yes \\
\hline N. Observations & 157,600 & 157,600 & 157,600 & 102,076 & 54,812 \\
\hline N. Job Matches & 41,965 & 41,965 & 41,965 & 27,121 & 15,058 \\
\hline F Instrument IV First Stage & & & 90.70 & 104.21 & 12.89 \\
\hline
\end{tabular}




\begin{tabular}{l|lll}
\hline \multicolumn{4}{l}{ Table A3: Quantile IV Fixed Effects Regressions of Wages on Quasi Rents. } \\
Instrument computed excluding Provinces within the Same Region. \\
\hline & $\mathbf{q} 10$ & $\mathbf{q} 50$ & $\mathbf{q 9 0}$ \\
\hline Ln Quasi Rent & $0.066^{* * *}$ & $0.057^{* * *}$ & $0.046^{* * *}$ \\
Ln Minimum Wage & $0.844^{* * *}$ & $0.836^{* * *}$ & $0.859^{* * *}$ \\
\hline Age & $0.039^{* * *}$ & $0.036^{* * *}$ & $0.030^{* * *}$ \\
Age Squared & $-0.000^{* * *}$ & $-0.000^{* * *}$ & $-0.000^{* * *}$ \\
Tenure 3-10 & $0.025^{* * *}$ & $0.007^{* * *}$ & -0.001 \\
Tenure >10 & $0.019^{* * *}$ & $0.002^{* *}$ & $-0.010^{* * *}$ \\
White Collar Dummy & $0.029^{* * *}$ & $0.030^{* * *}$ & $0.038^{* * *}$ \\
ln Firm Size & $0.049^{* * *}$ & $0.049^{* * *}$ & $0.049^{* * *}$ \\
Const & $2.976^{* * *}$ & $3.203^{* * *}$ & $3.269^{* * *}$ \\
\hline Region, Time and Sector dummies & yes & yes & yes \\
N. Observations & 157,600 & 157,600 & 157,600 \\
N. Job Matches & 41,965 & 41,965 & 41,965 \\
\hline \hline Nos: & &
\end{tabular}

Notes: ${ }^{* * *},{ }^{* *}$ and ${ }^{*}$ denote significance at $1 \%, 5 \%$ and $10 \%$ respectevely. 


\begin{tabular}{l|lll}
\hline Table A4: Quantile IV Fixed Effects Regressions of Wages on Quasi Rents. No Part-Time \\
\hline & q10 & q50 & q90 \\
\hline Ln Quasi Rent & $0.065^{* * *}$ & $0.054^{* * *}$ & $0.047^{* * *}$ \\
Ln Minimum Wage & $0.840^{* * *}$ & $0.844^{* * *}$ & $0.884^{* * *}$ \\
\hline Age & $0.039^{* * *}$ & $0.036^{* * *}$ & $0.030^{* * *}$ \\
Age Squared & $-0.000^{* * *}$ & $-0.000^{* * *}$ & $-0.000^{* * *}$ \\
Tenure 3-10 & $0.026^{* * *}$ & $0.007^{* * *}$ & $-0.002^{*}$ \\
Tenure >10 & $0.020^{* * *}$ & $0.003^{* * *}$ & $-0.010^{* * *}$ \\
White Collar Dummy & $0.031^{* * *}$ & $0.031^{* * *}$ & $0.037^{* * *}$ \\
ln Firm Size & $0.049^{* * *}$ & $0.048^{* * *}$ & $0.048^{* * *}$ \\
Const & $5.828^{* * *}$ & $5.990^{* * *}$ & $\begin{array}{l}\text { yes } \\
147,936 \\
39,240\end{array}$ \\
\hline $\begin{array}{l}\text { Region, Time and Sector dummies } \\
\text { N. Observations }\end{array}$ & $\begin{array}{l}\text { yes Matches } \\
147,936 \\
39,240\end{array}$ & \begin{tabular}{l} 
yes \\
147,936 \\
\hline N.
\end{tabular} &
\end{tabular}

Notes: ${ }^{* * *},{ }^{* *}$ and ${ }^{*}$ denote significance at $1 \%, 5 \%$ and $10 \%$ respectevely.

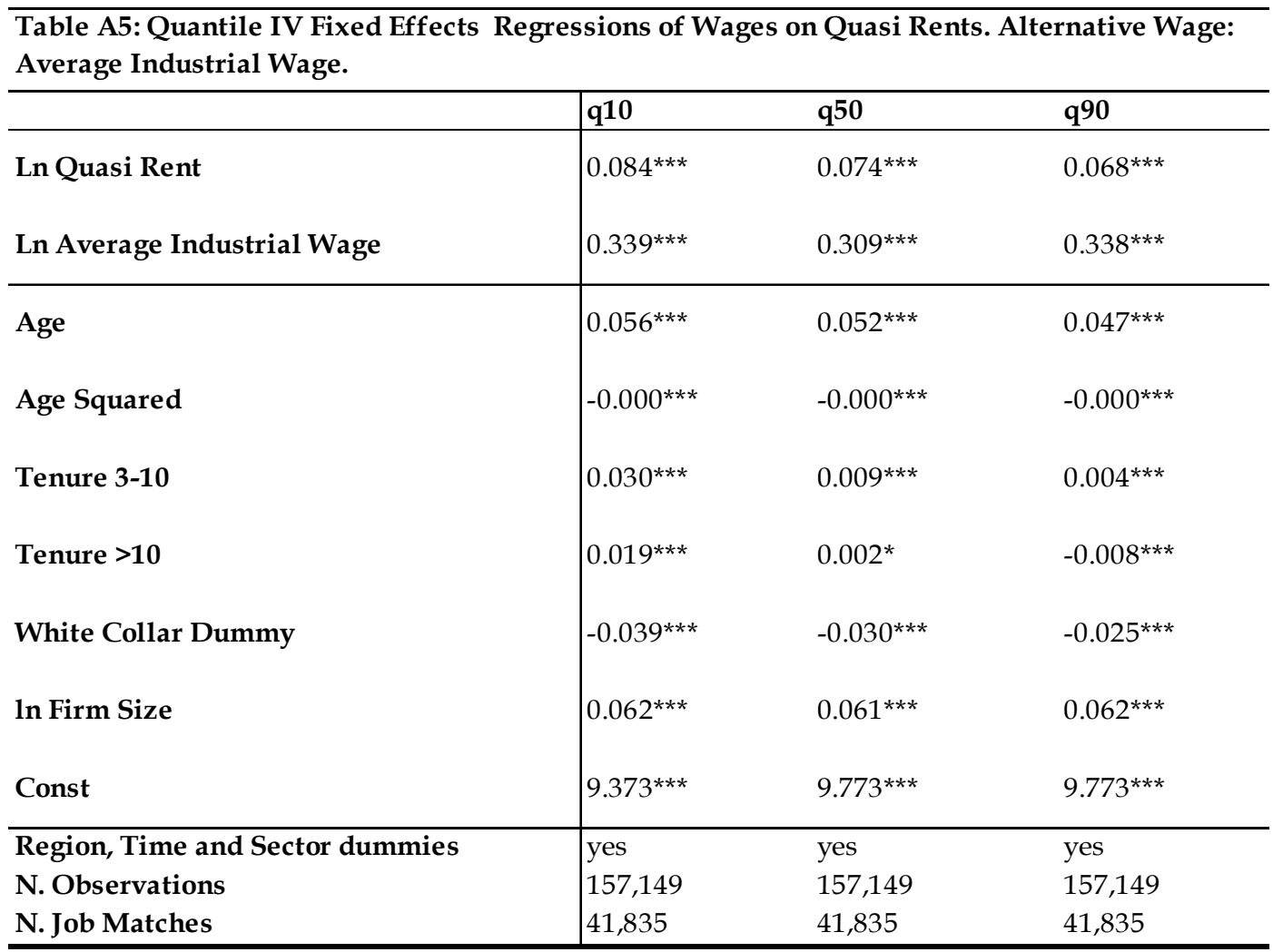

Notes: ${ }^{* * *},{ }^{* *}$ and ${ }^{*}$ denote significance at $1 \%, 5 \%$ and $10 \%$ respectevely. 
Table A6: Quantile IV Fixed Effects Regressions of Wages on Quasi Rents. Firm Size Dummies (Deciles)

\begin{tabular}{|c|c|c|c|}
\hline & q10 & $\mathrm{q} 50$ & $\mathrm{q90}$ \\
\hline Ln Quasi Rent & $0.058^{* * *}$ & $0.043^{* * *}$ & $0.039 * * *$ \\
\hline Ln Minimum Wage & $0.835^{* * *}$ & $0.831^{* * *}$ & $0.855^{* * *}$ \\
\hline Age & $0.041^{* * *}$ & $0.038^{* * *}$ & $0.032 * * *$ \\
\hline Age Squared & $-0.000 * * *$ & $-0.000 * * *$ & $-0.000 * * *$ \\
\hline Tenure 3-10 & $0.026^{* * *}$ & $0.006^{* * *}$ & -0.001 \\
\hline Tenure $>10$ & $0.020 * * *$ & $0.003^{* * *}$ & $-0.008^{* * *}$ \\
\hline White Collar Dummy & $0.031^{* * *}$ & $0.031^{* * *}$ & $0.039 * * *$ \\
\hline Const & $5.789 * * *$ & $6.017^{* * *}$ & $6.056^{* * *}$ \\
\hline Region, Time and Sector dummies & yes & yes & yes \\
\hline Firm Size Dummies & yes & yes & yes \\
\hline N. Observations & 157,600 & 157,600 & 157,600 \\
\hline N. Job Matches & 41,935 & 41,935 & 41,935 \\
\hline
\end{tabular}

Notes: ${ }^{* * * * *}$ and * denote significance at $1 \%, 5 \%$ and $10 \%$ respectevely. 
1 Alessia Matano, Universitat de Barcelona, AQR-IREA and University of Rome "La Sapienza", Dipartimento di Analisi Economiche e Sociali. Email: amatano@ub.edu.

2 Corresponding Author: Paolo Naticchioni, Roma Tre University and IZA, Via Chiabrera 199 00145 Rome (IT), email: p.naticchioni@gmail.com.

We are grateful to the research partnership between ISFOL (Rome) and Dipartimento di Analisi Economiche e Sociali - University "La Sapienza" of Rome, for access to the INPS, AIDA and RIL databases. We also thank Roger Koenker for his comments and for making his procedure available, Christian Dahl, Antonio Galvao and Christian Hansen for access to the routines and for suggestions concerning implementation of the quantile procedures, and participants in seminars at University of Barcelona, AIEL 2012 (Naples), LEED Workshop 2013 (Lisbon), EALE 2013 (Turin), SIE 2013 (Bologna), SAEe 2014 (Palma de Mallorca), RES 2015 (Manchester), ESPE 2015 (Izmir), ALDE 2015 (Alicante) conferences. We finally thank three anonymous referees for comments and useful suggestions. Alessia Matano gratefully acknowledges financial support from the Spanish Ministry of Economy and Competitiveness through the project ECO2016-75805-R.

${ }^{3}$ Note that also within a modified version of the competitive model it is possible to have a positive correlation between wages and profits. In particular, in the presence of short-run frictions, such as those experienced by firms facing an upward sloping labor supply curve, positive demand shocks could lead to a rise in total firm profits and wages (Hildreth and Oswald, 1997). However, in the long-run, wages adjust to the competitive level. Hence, a test for rent sharing cannot rest on the evidence of a short-run correlation between profits and wage.

${ }^{4}$ See also Martins (2007) for a survey of the main empirical results and methodologies applied in the rent sharing literature.

${ }^{5}$ Apart from Card et al (2014), very few published papers are available on rent sharing in Italy. We mention Matano and Naticchioni (2013) who investigate the extent of rent sharing in Italy from a gender perspective.

${ }^{6}$ Apart from the wage setting issue, the second level bargaining may also concern other work dimensions, such as hours worked, working conditions, etc. Furthermore, note also that in Italy workers can bargain at the individual level their wages, with the only constraint given by the minimum wage set by at the national level.

7 ISFOL stands for "Institute for the Development of Vocational Training". The sample scheme has been set up to follow individuals born on the $10^{\text {th }}$ of March, June, September and December and therefore the proportion of this sample on the Italian employees' population is approximately of $1 / 90$.

${ }^{8}$ For the information on employers we also make use of the ASIA ("Italian Statistical Archive of Operating Firms") database, provided by ISTAT. This database has been used since 1999, because the INPS employer database was no longer available as from 1998. The two databases provide the same set of information (firm size and sector).

${ }^{9}$ As a robustness check, in a previous version of the paper, we have focused on prime age workers to minimize issues related to labour force participation, and baseline results of the analysis were basically unaffected.

${ }^{10}$ The data have been deflated using the valued added deflator for value added, profits, sales, production and costs of production. The value added deflator is derived from our elaboration of ISTAT data on regional economic accounts and is defined at the sectoral and regional level. The base year is 2002 .

${ }^{11}$ Note that AIDA contains capital-owned firms with total value of production equal to or higher than 500,000 euro, while INPS data cover workers employed in all kinds of companies whatever the legal status and amount of total value of production. Therefore, it is possible to match only the INPS records of firms that are included in the AIDA database. For this reason, the merge concerns around $50 \%$ of the original INPS data.

${ }^{12}$ Wages have been deflated using as deflator the National Consumer Price Index (FOI index, Indice dei Prezzi al Consumo per le Famiglie di Operai e Impiegati, ISTAT). The base year is 2002.

${ }^{13}$ Note that in accounting profits per worker, capital costs are already deducted. See Martins (2009) for more details and for a derivation of a standard Nash bargaining problem, in which employers and workers choose employment and wage levels.

14 The number of different minimum wages, obtained by combining the number of different contracts and the occupational levels within the contracts, is on average 257 per year. The number of national contracts is on average 35 per year, while considering the entire sample time span we have the availability of 39 different contracts. 
${ }^{15}$ For a detailed description of the procedures applied see the Appendix in Matano and Naticchioni (2012) and Canay (2011), Galvao (2011) and Galvao and Montes-Rojas (2010).

${ }^{16}$ In particular, the main possible criticism to this IV approach is that industry-level shocks may be correlated with the unobserved determinants of wages, leading to a bias in the estimates. Card et al (2014) argue that such bias is most likely to arise in industrial districts (specialized local labour markets), where many of the alternative jobs for a given worker are in the same narrowly defined industry. When re-estimating the baseline specification dropping observations for firms in the most prevalent industry in industrial districts their results remain basically the same, suggesting the validity of the identifying assumption.

${ }^{17}$ The "Lester" range is defined as the elasticity of wages with respect to quasi-rent multiplied by four times the ratio between the standard deviation of quasi-rent and mean quasi-rent (Lester, 1952). It provides a measure of how much the wage of a worker increases moving from a firm at the bottom of the profit distribution (two standard deviations below the mean) to a firm at the top of the profit distribution (two standard deviations above the mean). In this paper we are unable to provide measures for the "Lester" range, since we are working with quantiles and not with average wages. For this reason we compute the Lester range associated to the OLS estimates shown in Table A2 in the Appendix.

${ }^{18}$ As for the control variable in the estimation, the results are as follow: the impact of minimum wage is positive and increasing along all the wage distribution and its elasticity is higher than 1, meaning that an increase in the minimum wage implies a more than proportional increase in the corresponding worker's wage; the age coefficients show a concave pattern, which is decreasing along the wage distribution; the gender wage gap is higher at the highest percentiles; the return to tenure is positive and decreasing along the wage distribution and the occupation dummy is positive and increasing, highlighting higher wages for white collar workers; the firm size has only a slightly positive and decreasing impact along the wage distribution.

19 Interestingly, the coefficient of minimum wage, which was increasing in the cross section estimates, is now constant along the wage distribution, and it will be generally the case also in the following estimates. This evidence suggests that the increasing trend observed in cross section estimates was actually driven by worker and firm unobserved heterogeneity.

${ }^{20}$ We perform equality tests of coefficients across different wage percentiles. In particular, we get a ttest value of 3.39 for the equality of coefficients between the $10^{\text {th }}$ and $50^{\text {th }}$ percentile; a t-test value of 3.15 for the equality of coefficients between the $50^{\text {th }}$ and the $90^{\text {th }}$ percentile, and a t-test value of 5.71 for the one between the $10^{\text {th }}$ and $90^{\text {th }}$ percentile. It is hence possible to reject the equality of coefficients across different percentiles at $99 \%$ of significance level.

${ }^{21}$ In particular, we have the availability of an average of 35 contracts per year distinguished also by blue collars and white collars, for a total of around 65 contracts per year, since some contracts do not apply for both workers' categories.

22 An additional issue is related to the fact that in our data there is no information about the amount of hours worked, but only about the number of full-time equivalent days/weeks worked during the year. One possible concern is that our results might be affected by differences along the wage distribution in the amount of extra-hours worked. We can only partially deal with this issue. For instance, in the robustness check in which we excluded part-time workers we impose a restriction in the amount of hours worked. In a similar way, the split between blue collar and white collar workers allows controlling for systematic difference between these occupation categories. However, this issue cannot be addressed in a satisfactory way using our administrative data. Hence, we have to stress that at least partially our results might be affected by differences in hours worked along the wage distribution.

${ }^{23}$ This heterogeneity within occupation categories also implies overlapping in terms of wages and skills across workers' categories. In fact, for instance a white collar worker at the 50th percentile of the white collars wage distribution has a lower wage with respect to a blue collar worker located at the 90th percentile of the blue collars wage distribution.

${ }^{24}$ Note that in Card et al. (2014) rent sharing is higher for blue collars. This difference is likely due to the fact that they consider only the Veneto region, a region that is highly specialized in the manufacturing sector. Unfortunately, we cannot carry out a check only for the Veneto region, since we cannot observe the universe of workers for this region as in Card et al (2014), but only a limited sample size, which is not enough to carry out reliable estimates (in particular considering only one region in our data the instrument turns out to be weak). 
${ }^{25}$ As for the institutional framework of unions, the Italian law gives the workers the right to join a union, engage in union activity and organize a plant-level union representation structure. The main workplace representation body is the so-called 'unitary workplace union structures' (Rappresentanze Sindacali Unitarie, RSU), and an alternative plant-level union body (Rappresentanza Sindacale Aziendale, RSA) can be elected by the members of a particular union. RSUs have tended to replace RSAs over time. Note also that in Italy unions and employees' representations are allowed to negotiate at the plant level over additional issues not tackled by the industry-wide bargaining, such as -apart from wages- performance pay and working conditions.

${ }^{26}$ The literature has also focused on the decline in manufacturing as a possible determinant of the fall in union density in the last decades (for the UK, see Disney, 1990).

${ }^{27}$ We use RIL in 2005 since it is the first available wave of the survey. Nonetheless, this should not be worrying since unionization is a persistent phenomenon.

${ }^{28}$ For this reason, the sample size of our estimates decreases, since not for all region/sector cells it is possible to associate a reliable union variable. As a check, all previous results apply also for this restricted sample.

${ }^{29}$ Recent studies by Di Nardo and Lee (2004), Lee and Mas (2012) and Frandsen (2012) use regression discontinuity design (RDD) techniques to identify the 'causal effect' of unions by comparing closely run union certification elections for the US case. For most of European countries, however, there are no such natural experiments to exploit, as unions do not generally need to win a majority election to be recognized as bargaining partners.

${ }^{30}$ We have also carried out the same estimates for the service sector. Results for blue collars are lower in magnitude, but still decreasing along the wage distribution, while for white collar they are higher in magnitude compared to the estimates for the whole economy. These estimates are available upon request.

${ }^{31}$ Note that the base effect for union is always negative. However, in this case, this coefficient has not a standard interpretation since it refers to the case in which the quasi-rent variable is equal to zero, which is never the case. 